\title{
Editorial: Biogenic Reefs at Risk: Facing Globally Widespread Local Threats and Their Interaction With Climate Change
}

\section{OPEN ACCESS}

Edited and reviewed by: Angel Borja,

Technological Center Expert in Marine and Food Innovation (AZTI), Spain

*Correspondence: Massimo Pont massimo.ponti@unibo.it

TORCID:

Massimo Ponti

orcid.org/0000-0002-6521-1330

Cristina Linares

orcid.org/0000-0003-3855-2743

Carlo Cerrano

orcid.org/0000-0001-9580-5546

Riccardo Rodolfo-Metalpa orcid.org/0000-0001-7054-1361

Bert W. Hoeksema orcid.org/0000-0001-8259-3783

Specialty section: This article was submitted to

Marine Ecosystem Ecology, a section of the journal

Frontiers in Marine Science

Received: 11 October 2021

Accepted: 23 October 2021

Published: 16 November 2021

Citation:

Ponti M, Linares C, Cerrano C,

Rodolfo-Metalpa $R$ and

Hoeksema BW (2021) Editorial:

Biogenic Reefs at Risk: Facing Globally Widespread Local Threats and Their Interaction With Climate Change. Front. Mar. Sci. 8:793038. doi: 10.3389/fmars.2021.793038

\author{
Massimo Ponti ${ }^{1,2 \times t}$, Cristina Linares ${ }^{3 \dagger}$, Carlo Cerrano ${ }^{2,4,5,6+}$, Riccardo Rodolfo-Metalpa ${ }^{7 t}$ \\ and Bert W. Hoeksema ${ }^{8,9+}$
}

${ }^{1}$ Dipartimento di Scienze Biologiche, Geologiche e Ambientali, University of Bologna, Ravenna, Italy, ${ }^{2}$ Consorzio Nazionale Interuniversitario per le Scienze del Mare (CoNISMa), Rome, Italy, ${ }^{3}$ Departament de Biologia Evolutiva, Ecologia i Ciències Ambientals, Institut de Recerca de la Biodiversitat, Universitat de Barcelona, Barcelona, Spain, ${ }^{4}$ Dipartimento di Scienze della Vita e dell'Ambiente, Polytechnic University of Marche, Ancona, Italy, ${ }^{5}$ Stazione Zoologica Anton Dohrn, Naples, Italy, ${ }^{6}$ Fano Marine Center, Fano, Italy, ${ }^{7}$ ENTROPIE, Institut de Recherche pour le Développement (IRD), Université de la Réunion, Centre National de la Recherche Scientifique (CNRS), Institut Français de Recherche pour l'Exploitation de la Mer (IFREMER), Université de Nouvelle-Calédonie, Nouméa, New Caledonia, ${ }^{8}$ Taxonomy, Systematics and Geodiversity Group, Naturalis Biodiversity Center, Leiden, Netherlands, ${ }^{9}$ Groningen Institute for Evolutionary Life Sciences, University of Groningen, Groningen, Netherlands

Keywords: bioconstruction, biodiversity, human impact, disturbance, ecological shift, marine conservation, resilience, citizen science

\section{Editorial on the Research Topic}

Biogenic Reefs at Risk: Facing Globally Widespread Local Threats and Their Interaction With Climate Change

\section{INTRODUCTION}

Biogenic reefs are secondary marine substrates, also referred to as bioconstructions or bioherms, made by autogenic ecosystem engineers (sensu, Jones et al., 1994) that provide habitats for various species. Their ecological role goes far beyond simple physical effects because they can modulate many resources and interactions between species inhabiting the reefs. Marine bioconstructions involve a variety of fragile three-dimensional habitats, from shallow water coral reefs to mesophotic coralligenous concretions, hosting rich, and diverse benthic assemblages (Cocito, 2004; Ingrosso et al., 2018; Cerrano et al., 2019). Biogenic reefs can be found from the intertidal to the deep sea; some are ephemeral and last a few years, while others remain active for millennia. The main framework builders are able to form bioconstructions at different latitudes, from tropical to polar zones, and include films of cyanobacteria and diatoms, calcareous rhodophytes, sponges, hermatypic symbiotic and aposymbiotic corals, polychaetes as serpulids and sabellariids, mollusks like vermetids, oysters and mussels, and bryozoans.

Biogenic reefs have an inestimable value for the biodiversity they host and the countless ecosystem goods and services they provide, which are only partially quantifiable in their economical values. Considering the time required for their formation, their destruction can often be considered almost irreversible, so bioconstructions require the utmost attention in any conservation measure. Indeed, both tropical and temperate biogenic reefs are increasingly threatened by multiple stressors resulting in the decline of reef communities worldwide (e.g., Harborne et al., 2017; Ellis et al., 2019; Maher et al., 2019; Bevilacqua et al., 2021). Natural and anthropogenic stressors include decline in water quality, overexploitation of resources, habitat destruction, and global climate change among others, which have all been linked in tropical and temperate areas with the occurrence of mass coral 
bleaching and a variety of diseases and mass mortality events (e.g., Carpenter et al., 2008; Garrabou et al., 2009; Ban et al., 2014; Burge et al., 2014; Thompson et al., 2014; Ponti et al., 2016; Gómez-Gras et al., 2021).

Many environmental stressors and anthropogenic disturbances are thought to favor the onset of infectious disease, either on their own or more commonly synergistically (Harvell et al., 2007). For example, anomalously high sea surface temperatures and their increasing frequency have been shown to raise coral susceptibility and pathogen virulence, influencing the severity, and rate of spread of infections (Randall et al., 2014; Wooldridge, 2014). Furthermore, disease susceptibility and the increase of corallivores has also been linked to stressing conditions as high sedimentation rates, water turbidity, eutrophication, and the development of diving tourism (e.g., Fabricius, 2005; Lamb et al., 2014; Pollock et al., 2014; Nicolet et al., 2018).

Nowadays, many studies focus on possible ecological effects of global climate change, which has resulted in massive worldwide coral bleaching in the tropics (e.g., Baker et al., 2008; Hughes et al., 2018), and in massive mortality events in the Mediterranean Sea (Ponti et al., 2014; Turicchia et al., 2018a; Garrabou et al., 2019; Gómez-Gras et al., 2021). Although it is not easy to categorize and disentangle the synergic effects of different threats, a simple literature review based on identified keywords related to the major threats highlighted how studies have mainly focused on climate change related issues and secondarily on pollution (Figure 1). Apparently, we are losing sight of the impacts on biogenic reefs associated with more "localized" disturbances, such as decline in water quality, overexploitation of resources, destructive fisheries, spread of non-indigenous species, recreational activities, and urbanization. Such stressors are increasing in intensity and frequency on a global scale and will therefore undoubtedly be playing a pivotal role in the health and functionality of biogenic reefs, especially about disease outbreaks, resilience to ecological shifts, and loss of ecological goods and services. This Frontiers Research Topic (RT) entitled "Biogenic Reefs at Risk: Facing Globally Widespread Local Threats and their Interaction with Climate Change," aims to fill the gaps by collecting new insights on worldwide biogenic reefs threats, advancing in monitoring technologies, and providing innovative perspectives on conservation and restorations strategies.

\section{EMERGING ISSUES}

Among the most relevant emerging issues that are not directly linked to climate change but are threatening biogenic reefs worldwide, there are newly discovered diseases, like the stony coral tissue loss disease which outbreaks are spreading fast in the Caribbean (Estrada-Saldívar et al., 2021; Heres et al., 2021; Meiling et al., 2021). Since we know very little about the origin of pathogens in corals, there is also a need for a better understanding of the etiology, the evolution, and biogeography of coral diseases (Montano et al., 2020).

Possible ecological cascading effects on biogenic reefs due to the spread of non-indigenous species are poorly known, among

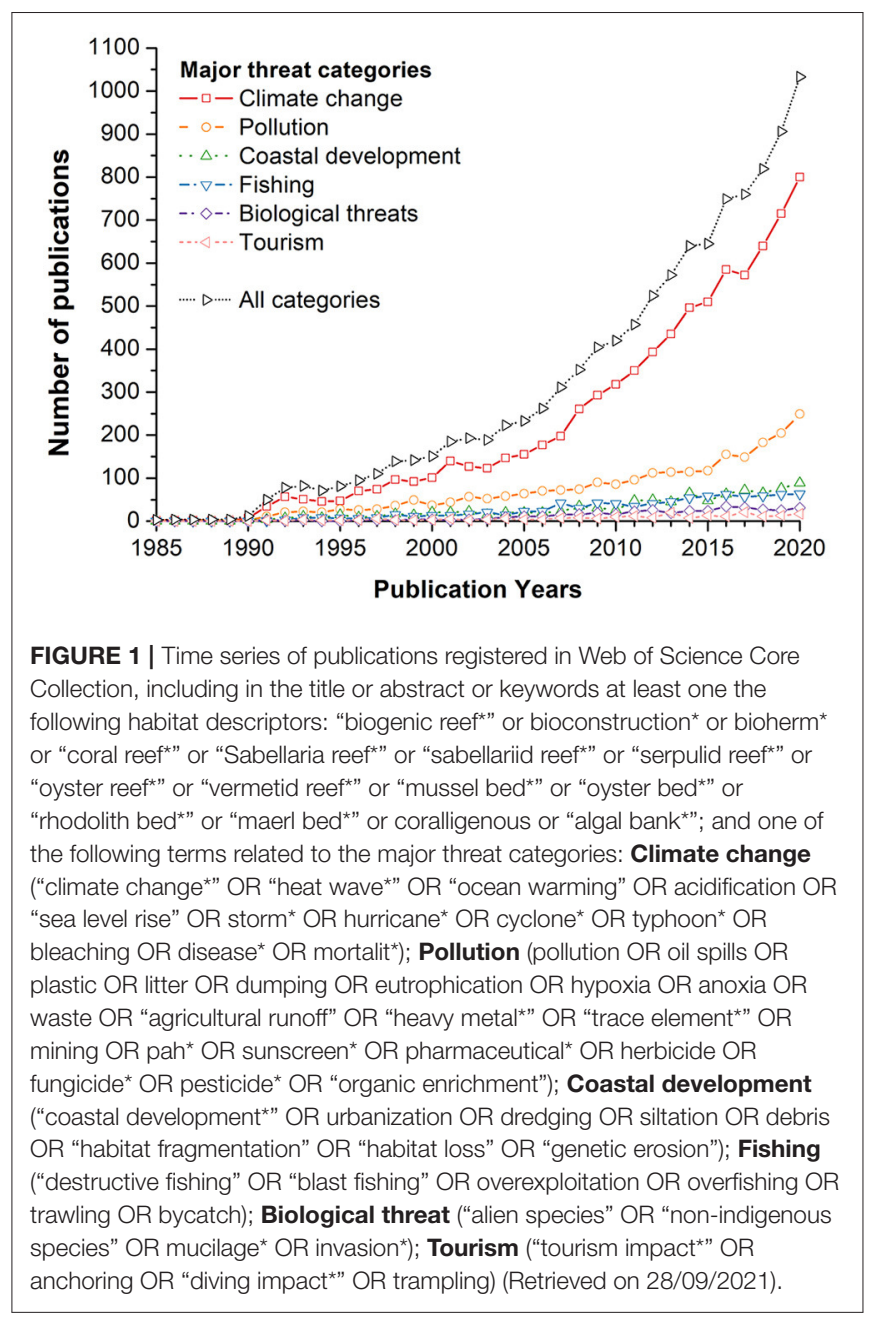

them those related to the invasion of lionfishes in the Caribbean (Pterois volitans; McCard et al., 2021) and the Mediterranean Sea (Pterois miles; Poursanidis et al., 2020), the rapid spread of invasive sun corals (Tubastraea spp.) in the (sub)tropical Atlantic because of shipping (Creed et al., 2017), and the increasing occurrence of various species of coral killing sponges in the IndoPacific ocean (e.g., Turicchia et al., 2018b; Fromont et al., 2019; Ashok et al., 2020), as well as the spreading of invasive macroalgae in Mediterranean temperate biogenic reefs (Kersting et al., 2013). A contribution to the understanding of trophic cascade effects in the conservation of temperate biogenic reefs was provided by the article published in this RT by Christie et al., whose experiments indicate that mesopredators such as the green crab (Carcinus maenas) and the goldsinny wrasse (Ctenolabrus rupestris) may be co-responsible for the decrease in blue mussel (Mytilus edulis) beds in northern Europe.

The pollution issues are very pronounced, especially in Southeast Asia (e.g., Heery et al., 2018; Adyasari et al., 2021; Reichert et al., 2021), and should not be underestimated also in other regions, especially concerning plastics and emerging pollutants in general, as highlighted in this RT by Angiolillo and Fortibuoni. Likewise, the negative impact 
of fishing activities is still underestimated in many regions, including developed countries, and especially regarding the deep biogenic reefs. Two manuscripts in this RT stressed the urgency to fill the knowledge gap on the current and predicted distribution, according to climate change scenarios, of the deep bioconstructions to protect them from fishing threats and maintain a pocket of pristine-like biodiversity (Dias et al.; Fragkopoulou et al.). Moreover, there is an increasing impact of land reclamation triggering devastating local dredging activities (e.g., Topçu et al., 2018; Pancrazi et al., 2020). In addition to the direct habitat removal, one of the main effects of land reclamation and coastal development, is the increase in water turbidity that can undermine the resilience of surrounding biogenic reefs, especially those with a strong dependence on light, as in the study carried out on Singapore' coral reefs and presented in this RT by Morgan et al.

Another threat to biogenic reefs that has received much attention is that of massive outbreaks of corallivores. Well-known examples are outbreaks of crown-of-thorns starfish (Acanthaster spp.) and gastropod snails of the genus Drupella, which may cause serious coral mortality (Turner, 1994; Pratchett et al., 2017). Whether there is a direct relation with climate change is not clear, but it is striking that such outbreaks can occur directly after massive coral bleaching event and may affect coral populations that have survived the bleaching (e.g., Hoeksema et al., 2013; Saponari et al., 2021).

\section{CONSERVATION MEASURES AND FUTURE PERSPECTIVES}

Information on many local, but globally spread, threats to biogenic reefs is still limited. Therefore, it is urgent to draw the most complete picture on these impacts including the multiple stressors acting in synergy with climate change effects. In this RT, Ford et al. and Montefalcone et al., although working in different geographical areas and with different approaches, similarly concluded that local human impacts can deeply alter the resilience of tropical coral reefs toward repeated climate change related disturbance events, jeopardizing the future of these ecosystems. To this end, field and manipulative experiments simulating effects of ecological shifts due to both pulse and press disturbances affecting biogenic reefs and modeling approaches that can provide insights into future trends should be strongly encouraged.

A widespread and standardized approach to analyzing the health of biogenic reefs in relation to local disturbances could help mitigate their effects and improve solutions. However, since climate change acts on a global scale, and many anthropogenic disturbances, although local, have a global spread, the conservation and restoration of our planet's biogenic reefs must be addressed with at least international approaches and policies (e.g., the European Green Deal and the European Biodiversity Strategy, the Coral Triangle Initiative). In this perspective, individual Marine Protected Areas can do little for the conservation of these habitats if they do not act synergistically as functional wide-area networks (Giakoumi et al., 2018). In this respect, Gazulla et al. contributed to the RT by providing a case study on the conservation and restoration of the red coral Corallium rubrum populations based on the connectivity network obtained by a demo-genetic approach. Similarly, citizen science initiatives are proving able to provide effective community-based monitoring at the regional or global level supplementing institutional actions (Sully et al., 2019; Turicchia et al., 2021).

Coastal development and coastal defense around the world are undergoing to a profound paradigm shift, passing from large concrete structures to nature-based solutions, including the application of new eco-friendly materials and shapes (Airoldi et al., 2021; Sella et al., 2021) that can favor the settlement of local species and, over time, the restoration of coastal biogenic reefs, such as coral reef and oyster beds. A better understanding of the effectiveness of such manmade structures would require more long-term research comparing the development of their communities with that of adjacent biogenic reefs (Perkol-Finkel et al., 2006; Hill et al., 2021; Monchanin et al., 2021).

Finally, from a technological perspective, three papers published within this RT highlighted that new measuring and monitoring tools, based both on underwater (Dellisanti et al.; Rossi et al.) and aerial platforms (Bajjouk et al.), can be developed, especially for the mapping and conservation of relatively shallow waters biogenic reefs.

The widespread and continuous alteration of biogenic reef ecosystems is affecting mainly ecosystem engineers, rapidly fragmenting their complex, and delicate trophic web, weakening the whole bioconstructions' architecture. This increasing fragility open the door to pathogens and non-indigenous species deeply compromising natural recovery and restoration strategies (Ponti et al., 2018; Verdura et al., 2019). Without an effective and rapid reduction of anthropogenic pressures on temperate and tropical bioconstructions we will not have any possibility to reverse the present rate of biodiversity loss.

Overall, the topic addressed here is very broad, embracing very different fragile marine ecosystems from tropical to temperate seas and the relationship humans have with their conservation and restoration. The diversity of the contributions collected in this RT focusing on different stressors and using different approaches and technologies to study biogenic reefs around the world reflects this complexity well. They provide new insights not only on the cumulative and synergic effects of multiple threats and their interaction with climate change in different systems but also stress on needs and gaps to advance in biogenic reefs monitoring, conservation, and restoration. These papers are aimed at a very wide audience, from scientists to managers and policymakers, as well as stakeholders involved in biogenic reefs goods and services. We believe they will support future advances to improve understanding of biogenic reefs conservation ecology, ultimately leading to a healthier ocean. We thank all contributing authors and are confident that readers will enjoy reading these papers on threats to biogenic reefs.

\section{AUTHOR CONTRIBUTIONS}

All authors contributed to writing and editing this editorial. Figure 1 was prepared by MP. All authors contributed to the article and approved the submitted version. 


\section{REFERENCES}

Adyasari, D., Pratama, M. A., Teguh, N. A., Sabdaningsih, A., Kusumaningtyas, M. A., and Dimova, N. (2021). Anthropogenic impact on Indonesian coastal water and ecosystems: current status and future opportunities. Mar. Pollut. Bull. 171, 112689. doi: 10.1016/j.marpolbul.2021.112689

Airoldi, L., Beck, M. W., Firth, L. B., Bugnot, A. B., Steinberg, P. D., and Dafforn, K. A. (2021). Emerging solutions to return nature to the urban ocean. Ann. Rev. Mar. Sci. 13, 445-477. doi: 10.1146/annurev-marine-032020-020015

Ashok, A. M., Calcinai, B., and Edward, J. K. P. (2020). The coral-killing red sponge Clathria (Microciona) aceratoobtusa (Porifera: Demosponigiae) invades various coral communities of Gulf of Mannar Marine National Park, southeast India. Eur. Zool. J. 87, 1-11. doi: 10.1080/24750263.2019.1708486

Baker, A. C., Glynn, P. W., and Riegl, B. (2008). Climate change and coral reef bleaching: an ecological assessment of long-term impacts, recovery trends and future outlook. Estuar. Coast. Shelf Sci. 80, 435-471. doi: $10.1016 /$ j.ecss.2008.09.003

Ban, S. S., Graham, N. A. J., and Connolly, S. R. (2014). Evidence for multiple stressor interactions and effects on coral reefs. Glob. Change Biol. 20, 681-697. doi: $10.1111 /$ gcb. 12453

Bevilacqua, S., Airoldi, L., Ballesteros, E., Benedetti-Cecchi, L., Boero, F., Bulleri, F., et al. (2021). Mediterranean rocky reefs in the anthropocene: present status and future concerns. Adv. Mar. Biol. 89, 1-51. doi: 10.1016/bs.amb.2021. 08.001

Burge, C. A., Mark Eakin, C., Friedman, C. S., Froelich, B., Hershberger, P. K., Hofmann, E. E., et al. (2014). Climate change influences on marine infectious diseases: implications for management and society. Ann. Rev. Mar. Sci. 6, 249-277. doi: 10.1146/annurev-marine-010213-135029

Carpenter, K. E., Abrar, M., Aeby, G., Aronson, R. B., Banks, S., Bruckner, A., et al. (2008). One-third of reef-building corals face elevated extinction risk from climate change and local impacts. Science. 321, 560-563. doi: 10.1126/science. 1159196

Cerrano, C., Bastari, A., Calcinai, B., Di Camillo, C., Pica, D., Puce, S., et al. (2019). Temperate mesophotic ecosystems: gaps and perspectives of an emerging conservation challenge for the Mediterranean Sea. Eur. Zool. J. 86, 370-388. doi: $10.1080 / 24750263.2019 .1677790$

Cocito, S. (2004). Bioconstruction and biodiversity: their mutual influence. Sci. Mar. 68, 137-144. doi: 10.3989/SCIMAR.2004.68S1137

Creed, J. C., Fenner, D., Sammarco, P., Cairns, S., Capel, K., Junqueira, A. O. R., et al. (2017). The invasion of the azooxanthellate coral Tubastraea (Scleractinia: Dendrophylliidae) throughout the world: history, pathways and vectors. Biol. Invasions 19, 283-305. doi: 10.1007/s10530-016-1279-y

Ellis, J. I., Jamil, T., Anlauf, H., Coker, D. J., Curdia, J., Hewitt, J., et al. (2019). Multiple stressor effects on coral reef ecosystems. Glob. Change Biol. 25, 4131-4146. doi: 10.1111/gcb.14819

Estrada-Saldívar, N., Quiroga-García, B. A., Pérez-Cervantes, E., Rivera-Garibay, O. O., and Alvarez-Filip, L. (2021). Effects of the stony coral tissue loss disease outbreak on coral communities and the benthic composition of cozumel reefs. Front. Mar. Sci. 8:632777. doi: 10.3389/fmars.2021.632777

Fabricius, K. E. (2005). Effects of terrestrial runoff on the ecology of corals and coral reefs: review and synthesis. Mar. Pollut. Bull. 50, 125-146. doi: 10.1016/j.marpolbul.2004.11.028

Fromont, J., Richards, Z. T., and Wilson, N. G. (2019). First report of the coralkilling sponge Terpios hoshinota Rützler and Muzik, 1993 in Western Australia: a new threat to Kimberley coral reefs? Diversity. 11:184. doi: 10.3390/d11100184

Garrabou, J., Coma, R., Bensoussan, N., Bally, M., Chevaldonne, P., Cigliano, M., et al. (2009). Mass mortality in Northwestern Mediterranean rocky benthic communities: effects of the 2003 heat wave. Glob. Change Biol. 15, 1090-1103. doi: 10.1111/j.1365-2486.2008.01823.x

Garrabou, J., Gómez-Gras, D., Ledoux, J.-B., Linares, C., Bensoussan, N., LópezSendino, P., et al. (2019). Collaborative database to track mass mortality events in the Mediterranean Sea. Front. Mar. Sci. 6:707. doi: 10.3389/fmars.2019.00707

Giakoumi, S., McGowan, J., Mills, M., Beger, M., Bustamante, R. H., Charles, A., et al. (2018). Revisiting "success" and "failure" of marine protected areas: a conservation scientist perspective. Front. Mar. Sci. 5:223. doi: $10.3389 /$ fmars.2018.00223

Gómez-Gras, D., Linares, C., Dornelas, M., Madin, J. S., Brambilla, V., Ledoux, J.-B., et al. (2021). Climate change transforms the functional identity of Mediterranean coralligenous assemblages. Ecol. Lett. 24, 1038-1051. doi: 10.1111/ele.13718

Harborne, A. R., Rogers, A., Bozec, Y. M., Mumby, P. J., and Annual, R. (2017). Multiple stressors and the functioning of coral reefs. Ann. Rev. Mar. Sci. 9, 445-468. doi: 10.1146/annurev-marine-010816-060551

Harvell, D., Jordan-Dahlgren, E., Merkel, S., Rosenberg, E., Raymundo, L., Smith, G., et al. (2007). Coral disease, environmental drivers, and the balance between coral and microbial associates. Oceanography. 20, 172-195. doi: 10.5670/oceanog.2007.91

Heery, E. C., Hoeksema, B. W., Browne, N. K., Reimer, J. D., Ang, P. O., Huang, D., et al. (2018). Urban coral reefs: degradation and resilience of hard coral assemblages in coastal cities of East and Southeast Asia. Mar. Pollut. Bull. 135, 654-681. doi: 10.1016/j.marpolbul.2018.07.041

Heres, M. M., Farmer, B. H., Elmer, F., and Hertler, H. (2021). Ecological consequences of stony coral tissue loss disease in the Turks and Caicos islands. Coral Reefs 40, 609-624. doi: 10.1007/s00338-021-02071-4

Hill, C. E. L., Lymperaki, M. M., and Hoeksema, B. W. (2021). A centuries-old manmade reef in the Caribbean does not substitute natural reefs in terms of species assemblages and interspecific competition. Mar. Pollut. Bull. 169, 112576. doi: 10.1016/j.marpolbul.2021.112576

Hoeksema, B. W., Scott, C., and True, J. D. (2013). Dietary shift in corallivorous Drupella snails following a major bleaching event at Koh Tao, Gulf of Thailand. Coral Reefs 32, 423-428. doi: 10.1007/s00338-012-1005-x

Hughes, T. P., Anderson, K. D., Connolly, S. R., Heron, S. F., Kerry, J. T., Lough, J. M., et al. (2018). Spatial and temporal patterns of mass bleaching of corals in the anthropocene. Science 359, 80-83. doi: 10.1126/science.aan8048

Ingrosso, G., Abbiati, M., Badalamenti, F., Bavestrello, G., Belmonte, G., Cannas, R., et al. (2018). Mediterranean bioconstructions along the Italian coast. $A d v$. Mar. Biol. 79, 61-136. doi: 10.1016/bs.amb.2018.05.001

Jones, C. G., Lawton, J. H., and Shachak, M. (1994). Organisms as ecosystem engineers. Oikos 69, 373-386. doi: 10.2307/3545850

Kersting, D. K., Ballesteros, E., De Caralt, S., and Linares, C. (2013) Invasive macrophytes in a marine reserve (Columbretes Islands, NW Mediterranean): spread dynamics and interactions with the endemic scleractinian coral Cladocora caespitosa. Biol. Invasions 16, 1599-1610. doi: 10.1007/s10530-013-0594-9

Lamb, J. B., True, J. D., Piromvaragorn, S., and Willis, B. L. (2014). Scuba diving damage and intensity of tourist activities increases coral disease prevalence. Biol. Conserv. 178, 88-96. doi: 10.1016/j.biocon.2014.06.027

Maher, R. L., Rice, M. M., McMinds, R., Burkepile, D. E., and Thurber, R. V. (2019). Multiple stressors interact primarily through antagonism to drive changes in the coral microbiome. Sci. Rep. 9:6834. doi: 10.1038/s41598-019-43274-8

McCard, M., South, J., Cuthbert, R. N., Dickey, J. W. E., McCard, N., and Dick, J. T. A. (2021). Pushing the switch: functional responses and prey switching by invasive lionfish may mediate their ecological impact. Biol. Invasions 23 , 2019-2032. doi: 10.1007/s10530-021-02487-7

Meiling, S. S., Muller, E. M., Lasseigne, D., Rossin, A., Veglia, A. J., MacKnight, N., et al. (2021). Variable species responses to experimental Stony Coral Tissue Loss Disease (SCTLD) exposure. Front. Mar. Sci. 8:670829. doi: $10.3389 /$ fmars.2021.670829

Monchanin, C., Mehrotra, R., Haskin, E., Scott, C. M., Plaza, P. U., Allchurch, A., et al. (2021). Contrasting coral community structures between natural and artificial substrates at Koh Tao, Gulf of Thailand. Mar. Environ. Res. 172:105505. doi: 10.1016/j.marenvres.2021.105505

Montano, S., Maggioni, D., Liguori, G., Arrigoni, R., Berumen, M. L., Seveso, D., et al. (2020). Morpho-molecular traits of Indo-Pacific and Caribbean Halofolliculina ciliate infections. Coral Reefs 39, 375-386. doi: 10.1007/s00338-020-01899-6

Nicolet, K. J., Chong-Seng, K. M., Pratchett, M. S., Willis, B. L., and Hoogenboom, M. O. (2018). Predation scars may influence host susceptibility to pathogens: evaluating the role of corallivores as vectors of coral disease. Sci. Rep. 8, 5258-5258. doi: 10.1038/s41598-018-23361-y

Pancrazi, I., Ahmed, H., Cerrano, C., and Montefalcone, M. (2020). Synergic effect of global thermal anomalies and local dredging activities on coral reefs of the Maldives. Mar. Pollut. Bull. 160:111585. doi: 10.1016/j.marpolbul.2020.111585

Perkol-Finkel, S., Shashar, N., and Benayahu, Y. (2006). Can artificial reefs mimic natural reef communities? The roles of structural features and age. Mar. Environ. Res. 61, 121-135. doi: 10.1016/j.marenvres.2005.08.001 
Pollock, F. J., Lamb, J. B., Field, S. N., Heron, S. F., Schaffelke, B., Shedrawi, G., et al. (2014). Sediment and turbidity associated with offshore dredging increase coral disease prevalence on nearby reefs. PLOS ONE 9:e102498. doi: 10.1371/journal.pone.0102498

Ponti, M., Fratangeli, F., Dondi, N., Segre Reinach, M., Serra, C., and Sweet, M. J. (2016). Baseline reef health surveys at Bangka Island (North Sulawesi, Indonesia) reveal new threats. PeerJ 4:e2614. doi: 10.7717/peerj.2614

Ponti, M., Perlini, R. A., Ventra, V., Grech, D., Abbiati, M., and Cerrano, C. (2014). Ecological shifts in Mediterranean coralligenous assemblages related to gorgonian forest loss. PLoS ONE 9, e102782. doi: 10.1371/journal.pone.0102782

Ponti, M., Turicchia, E., Ferro, F., Cerrano, C., and Abbiati, M. (2018). The understorey of gorgonian forests in mesophotic temperate reefs. Aquat. Conserv. 28, 1153-1166. doi: 10.1002/aqc.2928

Poursanidis, D., Kalogirou, S., Azzurro, E., Parravicini, V., Bariche, M., and Dohna, H. Z. (2020). Habitat suitability, niche unfilling and the potential spread of Pterois miles in the Mediterranean Sea. Mar. Pollut. Bull. 154:111054. doi: 10.1016/j.marpolbul.2020.111054

Pratchett, M., Caballes, C., Wilmes, J., Matthews, S., Mellin, C., Sweatman, H., et al. (2017). Thirty years of research on crown-of-thorns starfish (1986-2016): scientific advances and emerging opportunities. Diversity 9:41. doi: $10.3390 / \mathrm{d} 9040041$

Randall, C. J., Jordan-Garza, A. G., Muller, E. M., and Van Woesik, R. (2014). Relationships between the history of thermal stress and the relative risk of diseases of Caribbean corals. Ecology 95, 1981-1994. doi: 10.1890/13-0774.1

Reichert, J., Tirpitz, V., Anand, R., Bach, K., Knopp, J., Schubert, P., et al. (2021). Interactive effects of microplastic pollution and heat stress on reef-building corals. Environ. Pollut. 290:118010. doi: 10.1016/j.envpol.2021.118010

Saponari, L., Dehnert, I., Galli, P., and Montano, S. (2021). Assessing population collapse of Drupella spp. (Mollusca: Gastropoda) 2 years after a coral bleaching event in the Republic of Maldives. Hydrobiologia 848, 2653-2666. doi: 10.1007/s10750-021-04546-5

Sella, I., Hadary, T., Rella, A., Riegl, B., Swack, D., and Perkol-Finkel, S. (2021). Design, production and validation of the biological and structural performance of an ecologically engineered concrete block mattress: A Nature Inclusive Design for shoreline and offshore construction. Integr. Environ. Assess. Manag. doi: $10.1002 /$ ieam. 4523

Sully, S., Burkepile, D. E., Donovan, M. K., Hodgson, G., and van Woesik, R. (2019). A global analysis of coral bleaching over the past two decades. Nat. Commun. 10:1264. doi: 10.1038/s41467-019-09238-2

Thompson, A., Schroeder, T., Brando, V. E., and Schaffelke, B. (2014). Coral community responses to declining water quality: Whitsunday Islands, Great Barrier Reef, Australia. Coral Reefs 33, 923-938. doi: $10.1007 / \mathrm{s} 00338-014-1201-y$
Topçu, N. E., Turgay, E., Yardimci, R. E., Topaloglu, B., Yüksek, A., Steinum, T. M., et al. (2018). Impact of excessive sedimentation caused by anthropogenic activities on benthic suspension feeders in the Sea of Marmara. J. Mar. Biol. Assoc. UK 99, 1075-1086. doi: 10.1017/S0025315418001066

Turicchia, E., Abbiati, M., Sweet, M., and Ponti, M. (2018a). Mass mortality hits gorgonian forests at Montecristo Island. Dis. Aquat. Org. 131, 79-85. doi: $10.3354 /$ dao03284

Turicchia, E., Cerrano, C., Ghetta, M., Abbiati, M., and Ponti, M. (2021). MedSens index: the bridge between marine citizen science and coastal management. Ecol. Indic. 122:107296. doi: 10.1016/j.ecolind.2020.107296

Turicchia, E., Hoeksema, B. W., and Ponti, M. (2018b). The coralkilling sponge Chalinula nematifera as a common substrate generalist in Komodo National Park, Indonesia. Mar. Biol. Res. 14, 827-833. doi: $10.1080 / 17451000.2018 .1544420$

Turner, S. J. (1994). The biology and population outbreaks of the corallivorous gastropod Drupella on Indo-Pacific reefs. Oceanogr. Mar. Biol. Annu. Rev. $32,461-530$.

Verdura, J., Linares, C., Ballesteros, E., Coma, R., Uriz, M. J., Bensoussan, N., et al. (2019). Biodiversity loss in a Mediterranean ecosystem due to an extreme warming event unveils the role of an engineering gorgonian species. Sci. Rep. 9:5911. doi: 10.1038/s41598-019-41929-0

Wooldridge, S. A. (2014). Differential thermal bleaching susceptibilities amongst coral taxa: re-posing the role of the host. Coral Reefs 33, 15-27. doi: 10.1007/s00338-013-1111-4

Conflict of Interest: The authors declare that the research was conducted in the absence of any commercial or financial relationships that could be construed as a potential conflict of interest.

Publisher's Note: All claims expressed in this article are solely those of the authors and do not necessarily represent those of their affiliated organizations, or those of the publisher, the editors and the reviewers. Any product that may be evaluated in this article, or claim that may be made by its manufacturer, is not guaranteed or endorsed by the publisher.

Copyright $\odot 2021$ Ponti, Linares, Cerrano, Rodolfo-Metalpa and Hoeksema. This is an open-access article distributed under the terms of the Creative Commons Attribution License (CC BY). The use, distribution or reproduction in other forums is permitted, provided the original author(s) and the copyright owner(s) are credited and that the original publication in this journal is cited, in accordance with accepted academic practice. No use, distribution or reproduction is permitted which does not comply with these terms. 